\begin{tabular}{|c|c|c|}
\hline 7 & Our Nature & $\begin{array}{l}\text { ISSN: 1991-2951 (Print) } \\
\text { ISSN: 2091-2781 (Online) }\end{array}$ \\
\hline 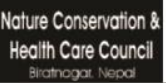 & Journal homepage: http://nepjol.info/index.php/ON & (c) (1) (8) \\
\hline
\end{tabular}

\title{
Roles of Cooperatives in Fish Farming Development in Chitwan and Nawalparasi Susta East Districts
}

\author{
Sabina Rajthala ${ }^{1}$, Sunila Rai ${ }^{{ }^{*}}$, Dilip K. Jha ${ }^{1}$, Jay Dev Bista ${ }^{1}$, Roseanna Avento ${ }^{2}$ \\ ${ }^{1}$ Agriculture and Forestry University, Rampur, Chitwan, Nepal \\ ${ }^{2}$ University of Eastern Finland, Yliopistonranta 1, P.O. Box 1627, 70211, Kuopio, Finland \\ *E-mail: sunilarai10@gmail.com
}

\begin{abstract}
A study was conducted to assess the role of cooperatives in improving fish farming through a comparison of fish farmers engaged and not engaged in cooperatives. Altogether, 140 fish farmers were selected from Chitwan and Nawalparasi Susta East district, 70 from each district. Annual income from fish production and annual total income was found significantly higher $(p<0.05)$ in non-cooperative fish farmers than cooperative fish farmers in Nawalparasi Susta East. The latter district has more fish farmers that have large-scale commercial operations. Fish farmers in cooperatives are mostly small-holders, whose production is consumed domestically. Non-cooperative fish farmers faced more $(\mathrm{P}>0.05)$ challenges than cooperative farmers especially in terms of seed quality and quantity. Cooperatives were attractive for their support in saving and micro-finance schemes. The study advocates for increased support to establishment of cooperatives as they have great potential to develop fish farming sustainably and to empower their members socially and economically.
\end{abstract}

Key words: Fish production, fish farmer, fish farmer cooperative, farmer organisation, small-holder

DOI: https://doi.org/10.3126/on.v18i1.34236

Manuscript details: Received: 15.11.2020 / Accepted: 5.12.2020

Citation: Rajthala, S., S. Rai, D.K. Jha, J.D. Bista and R. Avento 2020. Roles of Cooperatives in Fish Farming Development in Chitwan and Nawalparasi Susta East Districts. Our Nature 18 (1): 1-9. DOI: http://doi.org/10.3126/on.v18i1.34236

Copyright: Rajthala, Rai, Jha, Bista and Avento. Creative Commons Attribution - Non Commercial 4.0 International License.

\section{Introduction}

Aquaculture in Nepal is flourishing each fiscal year with increment of annual fish production and number of fish farmers (Budhathoki and Sapkota, 2018; CFPCC, 2019). Total aquaculture production was $70,832 \mathrm{mt}$ in the fiscal year $2018 / 19$ which was $8 \%$ higher than the previous year (CFPCC, 2019). There are 52,726 families involved in fish farming (CFPCC, 2019) in Nepal and the majority are small-holder fish farmers. Small-holder fish farmers have limited access to resources for production, credit, information, and markets affecting production on the one hand, while on the other hand they cannot reliably consistently supply traders with the amounts of fish needed (Kemkhadze, 2017). Establishing and joining fish farmer cooperatives enables small-holder fish farmers' access to input and markets that could enhance their returns (Ortman and King, 2007). Cooperatives help improve member farmers' returns by buying and selling in bulk and thus attaining better prices for their products. This is particularly important in Nepal where average farm size is small, with individual farmers only buying small amounts of inputs and selling small amounts of produce (Kemkhadze, 2017). 


\section{Our Nature | December 2020 | 18 (1): 1-9}

In Nepal, there are 34,512 cooperatives registered and among these 13,578 are saving and credit cooperatives and 10,921 are agriculture cooperatives (DEOC, 2020). There is no national database for fish farmer cooperatives probably due to their low number, thus the number of fish farmer cooperatives and the number of fish farmers engaged in the fish farmer cooperatives are not known exactly. Some estimations however exist for women fish farmer cooperatives in Chitwan and Nawalparasi Susta East districts, since women fish farmer empowerment projects supporting farmer organisations (FOs) have been implemented since 2012 with the support of the Finnish government and the agri-agency, Food and Forest Development Finland (FFD). Almost 300 women fish farmers in these districts are organized into three cooperatives and five selfhelp groups (Woynarovich, 2017).

Under normal circumstance cooperatives play significant role in the economic development of a nation (Ndifon et al., 2012). In Nepal, cooperatives are considered as one of the three pillars for national development (NPC, 2019). Cooperatives and other similar FOs are found to be very powerful and supportive organizations in the fisheries and aquaculture sector, and their contribution is found remarkable in the development of fish farming and marketing of fish globally. For instance the Network of Aquaculture Centres in the Asia-Pacific (NACA) surveyed 400 fish farmer FOs in the AsiaPacific region in 1997-98 and highlighted their most common activities as: highlighting farmer problems, mobilizing public and institutional support for farmers, protecting the interests of the FO, providing technical services to members, becoming organized to resist exploitation by intermediaries and local pressure groups, mobilizing credit and influencing policy decision (Hough and Bueno, 2002).

However, the role and impacts of cooperatives including fish farming cooperatives on sustainable development of small-scale fish farming has not been comprehensively assessed yet in Nepal. This study therefore aims to examine the effects of cooperatives on fish farming, and identifies the challenges faced by fish farmers by comparing cooperative and non- cooperative fish farmers in Chitwan and Nawalparasi Susta East districts. Cooperative farmers included fish farmers engaged in any cooperatives such as agriculture cooperatives, fish farmers cooperatives, dairy cooperatives, etc., whereas non-cooperative farmers included fish farmers who are not engaged in any cooperative. They are fish farmers either engaged in self-help groups or independent fish farmers. The study also seeks to identify the perception of farmers towards cooperatives to prepare a basis for improved policies in cooperative development in Nepal.

\section{Methodology \\ Study site}

A fish farmers survey was carried in Chitwan and Nawalparasi Susta Purba or East (locally called Nawalpur district) districts. Five municipalities Bharatpur, Ratnanagar, Khaireni, Rapti and Madi from Chitwan district and three municipalities Madhyabindu, Kawasoti and Depchuli from Nawalpur district were selected based on fish production.

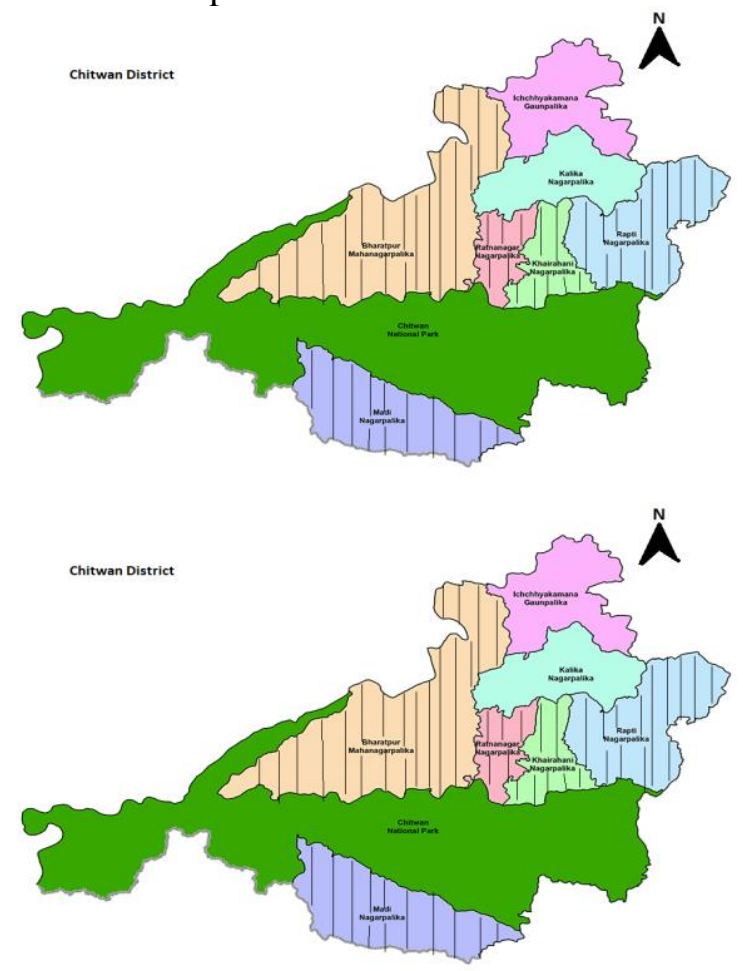

Figure 1. Map of Chitwan and Nawalpur districts showing the study area marked with vertical line. 


\section{Our Nature | December 2020 | 18 (1): 1-9}

\section{Sample size and sampling procedure}

A total of 140 fish farmers, 70 farmers from each district, were selected randomly and interviewed. Among the total respondents from the Chitwan districts, 35 were non-cooperative fish farmers and 35 were cooperative farmers. Similarly, 40 respondents were non-cooperative farmers and 30 were cooperative farmers in Nawalpur district. There are 704 and 474 cooperatives in Chitwan and Nawalpur among them three in Chitwan and two in Nawalpur are fish farmers cooperatives (DEOC, 2020).

\section{Data collection and analysis}

Data were obtained using primary and secondary sources. For the primary data, farmers were interviewed using a structured questionnaire while the secondary data were collected from related journals, books, related publications, official reports and relevant websites. The collected data were analyzed using IBM SPSS statistics 23 and Excel spread sheet 2016. Descriptive and analytical tools were used for the analysis of data. Variables such as respondent's age, gender, education level, family size, land holding, income pattern etc. were analyzed by using descriptive tools such as frequencies, percentage, mean, and standard deviation. Besides these, independent t-test and Chi-square test were used to determine whether there were difference between cooperative and non- cooperative farmers on various attributes within the district.

\section{Results \\ Socio-demographic characteristics of fish farmers}

Socio-demographic characteristics of cooperative and non-cooperative fish farmers included age, gender, level of education, family size (Table 1). Among the total 70 respondents from Chitwan, 36 were male and 34 were female. Considering cooperative and noncooperative categories of respondents, $54 \%$ were male and $46 \%$ were female among cooperative fish farmers whereas $49 \%$ were male and $51 \%$ were female among non-cooperative fish farmers in Chitwan. In Nawalpur district, 52 were male and only 18 were female. Among cooperative fish farmers $70 \%$ respondents were male and $30 \%$ were female, and among non-cooperative farmers $78 \%$ were male and $22 \%$ were female. The overall count of males was greater than that of females in both cooperative and noncooperative categories. The majority of respondents in Chitwan and Nawalpur belonged to the age group of 40-50 years. The higher number of women fish farmers in Chitwan compared to Nawalpur (34 in Chitwan and 18 in Nawalpur) is attributed to the women fish farmer empowerment projects implemented in the district.

Table 1. Socio-demographic characteristics of cooperative and non-cooperative fish farmers in Chitwan and Nawalpur district.

\begin{tabular}{clllll}
\hline District & & \multicolumn{2}{c}{ Chitwan } & \multicolumn{2}{c}{ Nawalpur } \\
\hline Gender & Male & $19(54 \%)$ & $17(49 \%)$ & $21(70 \%)$ & $31(78 \%)$ \\
& Cooperative & $\begin{array}{c}\text { Non- } \\
\text { cooperative }\end{array}$ & Cooperative & $\begin{array}{c}\text { Non- } \\
\text { cooperative }\end{array}$ \\
& Female & $16(46 \%)$ & $18(51 \%)$ & $9(30 \%)$ & $9(22 \%)$ \\
& $<30$ & $0(0 \%)$ & $5(14 \%)$ & $5(16 \%)$ & $6(15 \%)$ \\
& $30-40$ & $11(31 \%)$ & $11(32 \%)$ & $9(30 \%)$ & $7(18 \%)$ \\
& $40-50$ & $12(34 \%)$ & $14(40 \%)$ & $8(27 \%)$ & $13(32 \%)$ \\
Education & No education & $12(34 \%)$ & $5(14 \%)$ & $8(27 \%)$ & $14(35 \%)$ \\
& Primary level & $3(8 \%)$ & $6(17 \%)$ & $4(13 \%)$ & $11(28 \%)$ \\
& Secondary level & $16(46 \%)$ & $10(40 \%)$ & $6(20 \%)$ & $9(22 \%)$ \\
& SLC & $1(3 \%)$ & $1(3 \%)$ & $13(43 \%)$ & $9(22 \%)$ \\
& SLC above & $1(3 \%)$ & $4(11 \%)$ & $4(13 \%)$ & $7(18 \%)$ \\
& Small & $11(32 \%)$ & $12(34 \%)$ & $10(33 \%)$ & $4(10 \%)$ \\
& Medium & $18(51 \%)$ & $14(40 \%)$ & $12(40 \%)$ & $24(60 \%)$ \\
& Large & $6(17 \%)$ & $9(26 \%)$ & $8(27 \%)$ & $5(13 \%)$ \\
\hline
\end{tabular}




\section{Socio-economic characteristics of fish farmers}

Socio-economic characteristics of cooperative and non-cooperative fish farmers included pond size, number of ponds, fish production and income (Table 2). Pond size, number of ponds, fish production and income did not vary between cooperative and non-cooperative fish farmers in Chitwan while pond size, annual income from fish farming and total annual income were significantly $(\mathrm{P}<0.05)$ higher in the noncooperative fish farmers category than in the cooperative fish farmers category in Nawalpur. Average land size of sampled cooperative and non-cooperative fish farmers was 0.64 and 0.71 ha respectively in Chitwan and 0.51 and 0.94 ha in Nawalpur, respectively. The number of ponds owned by cooperative and non-cooperative fish farmers were 1.5 and 1.9 in Chitwan and 2.4 and 3.4 in Nawalpur district. The pond area was significantly $(\mathrm{P}<0.05)$ higher for noncooperative fish farmers (1.1 ha/household) than for cooperative fish farmers (0.34 ha/fish farmer) in Nawalpur. The average pond area in the farm was 0.25 and $0.21 \mathrm{ha} /$ fish farmer for cooperative and non-cooperative fish farmers in Chitwan, respectively. The annual fish production for cooperative and non-cooperative fish farmers was 608.3 and $507.7 \mathrm{~kg}$ in Chitwan and 897 and $4,782 \mathrm{~kg}$ in Nawalpur. The average annual fish production, annual income from fish sale and total household income of cooperative fish farmers were calculated as $608 \mathrm{~kg}$, Rs.1,96,857 and Rs. 4,92,857 respectively, and that for noncooperative fish farmers were $508 \mathrm{~kg}$, Rs.1,42,748 and Rs. 4,11,429, respectively in Chitwan. The average annual income from fish sale and total household income were found to be significantly $(\mathrm{P}<0.05)$ higher in noncooperative fish farmers (Rs. 8,11,265 and Rs. 9,40,000) than cooperative fish farmers (Rs. 2,43,210 and Rs. 4,15,000) in Nawalpur.

Table 2. Socio-economic characteristics (Mean \pm SD) of cooperative and non-cooperative fish farmers in Chitwan and Nawalpur districts

\begin{tabular}{llll}
\hline \multicolumn{1}{c}{ Land size (katha) } & \multicolumn{1}{c}{ Group } & \multicolumn{1}{c}{ Chitwan } & \multicolumn{1}{c}{ Nawalpur } \\
& Cooperative & $19.0 \pm 13.3^{\mathrm{a}}$ & $14.7 \pm 12.8^{\mathrm{a}}$ \\
No of ponds & Non-cooperative & $21.3 \pm 16.5^{\mathrm{a}}$ & $28.0 \pm 41.8^{\mathrm{a}}$ \\
& Cooperative & $1.5 \pm 0.9^{\mathrm{a}}$ & $2.4 \pm 1.5^{\mathrm{a}}$ \\
Pond area (katha/household) & Non-cooperative & $1.9 \pm 1.3^{\mathrm{a}}$ & $3.4 \pm 2.6^{\mathrm{a}}$ \\
& Cooperative & $6.2 \pm 6.5^{\mathrm{a}}$ & $10.2 \pm 9.5^{\mathrm{b}}$ \\
Annual fish production & Non-cooperative & $7.3 \pm 10.7^{\mathrm{a}}$ & $32.1 \pm 39.9^{\mathrm{a}}$ \\
(kg/households) & Cooperative & $608.3 \pm 526.5^{\mathrm{a}}$ & $897 \pm 1098^{\mathrm{a}}$ \\
$\begin{array}{ll}\text { Annual income } \quad \text { from } \\
\text { (Rs./household) }\end{array}$ & Non-cooperative & $507.7 \pm 840.3^{\mathrm{a}}$ & $4782 \pm 12738^{\mathrm{a}}$ \\
Annual income (Rs./household) & Cooperative & $196857.1 \pm 186512.5^{\mathrm{a}}$ & $243210 \pm 316663^{\mathrm{b}}$ \\
& Non-cooperative & $142748.5 \pm 113845.1^{\mathrm{a}}$ & $811265 \pm 1059337^{\mathrm{a}}$ \\
& Cooperative & $492857.1 \pm 212527.8^{\mathrm{a}}$ & $415000 \pm 421235^{\mathrm{b}}$ \\
& Non-cooperative & $411428.5 \pm 216959.5^{\mathrm{a}}$ & $940000 \pm 956636^{\mathrm{a}}$ \\
\hline
\end{tabular}

Mean values with different superscript letters in the same column are significantly different between cooperative and non-cooperative farmers within the same district $(\mathrm{P}>0.05)$.

\section{Fish farmers' involvement in cooperatives}

Fish farmers were found to have involvement in agriculture cooperatives, fish farmers cooperatives, multipurpose cooperatives, dairy cooperatives and forestry cooperatives. The majority of respondents were involved in fish farmer self-help groups in both Chitwan (47\%) and Nawalpur (49\%) districts followed by the agriculture cooperatives (17\%). The result revealed that only $21 \%$ and $11 \%$ of fish farmers in Chitwan and Nawalpur were engaged in fish farmer cooperatives. Similarly $3 \%$ and $9 \%$ fish farmers were not engaged in any FOs in Chitwan and Nawalpur districts, respectively. 
Our Nature | December 2020 | 18 (1): 1-9

Table 3. Types of organizations the sampled fish farmers engage with in Chitwan and Nawalpur districts

\begin{tabular}{lrrrr}
\hline & \multicolumn{2}{c}{ Chitwan } & \multicolumn{2}{c}{ Nawalpur } \\
\cline { 2 - 5 } & Frequency & Percentage (\%) & Frequency & Percentage (\%) \\
\hline Self-help group & 33 & 47.1 & 34 & 48.6 \\
Agriculture cooperative & 12 & 17.1 & 12 & 17.1 \\
Fish farmers cooperative & 15 & 21.4 & 8 & 11.4 \\
Multipurpose cooperative & 3 & 7.1 & 8 & 11.4 \\
Dairy cooperative & 5 & 7.1 & 0 & 0.0 \\
Forestry cooperative & 0 & 0.0 & 2 & 2.9 \\
None & 2 & 2.9 & 6 & 8.6 \\
Total & $\mathbf{7 0}$ & $\mathbf{1 0 0 . 0}$ & $\mathbf{7 0}$ & $\mathbf{1 0 0 . 0}$ \\
\hline
\end{tabular}

\section{Challenges faced by fish farmers}

In general, the data shows that fish farmers in Chitwan suffer fewer challenges than their counterparts in Nawalpur (Table 4). In Chitwan, the major challenge for non-cooperative fish farmers is quality and quantity of seed and diseases. On the whole, cooperative fish farmers in Chitwan, did not acknowledge any major challenges that were listed. In Nawalpur, both cooperative and non-cooperative fish farmers suffer problems in quality and quantity of feed, whereas non-cooperative fish farmers suffer more disease problems than cooperative farmers. In Nawalpur most cooperative fish farmers mentioned quality and quantity of seed as a problem. Non-cooperative fish farmers in Nawalpur, however, were more equally divided on this issue, with no significant difference between those that indicated that they have problems and those indicating that they do not. In general, the data shows that on the whole cooperative farmers suffer fewer challenges that non-cooperative farmers.

Table 4. Challenges faced by fish farmers in Chitwan and Nawalpur districts

\begin{tabular}{|c|c|c|c|c|c|c|c|}
\hline \multicolumn{8}{|c|}{ Chitwan Nawalpur } \\
\hline Problems & Group & Yes & No & $\chi^{2}$ & Yes & No & $\chi^{2}$ \\
\hline \multirow[t]{2}{*}{ Quality and quantity of seed } & Cooperative & 5 & 30 & & 22 & 8 & \\
\hline & Non-cooperative & 28 & 7 & $30 *$ & 18 & 22 & 5.6 \\
\hline \multirow[t]{2}{*}{ Quality and quantity of feed } & Cooperative & 0 & 35 & & 30 & 0 & \\
\hline & Non-cooperative & 6 & 29 & $7 *$ & 30 & 10 & $8.7 *$ \\
\hline \multirow{2}{*}{$\begin{array}{l}\text { Quality } \\
\text { fertilizer }\end{array}$} & of Cooperative & 0 & 35 & & 30 & 0 & \\
\hline & Non-cooperative & 16 & 19 & $21 *$ & 39 & 1 & 0.7 \\
\hline \multirow[t]{2}{*}{ Disease } & Cooperative & 0 & 35 & & 0 & 30 & \\
\hline & Non-cooperative & 12 & 23 & $14^{*}$ & 28 & 12 & $35^{*}$ \\
\hline \multirow[t]{2}{*}{ Labour } & Cooperative & 0 & 35 & & 24 & 6 & \\
\hline & Non-cooperative & 1 & 34 & 1 & 29 & 11 & 0.5 \\
\hline \multirow[t]{2}{*}{ Farming practice } & Cooperative & 0 & 35 & & 30 & 0 & \\
\hline & Non-cooperative & 0 & 35 & 1 & 40 & 0 & 1 \\
\hline \multirow[t]{2}{*}{ Water quality } & Cooperative & 0 & 35 & & 27 & 3 & \\
\hline & Non-cooperative & 1 & 34 & 1 & 34 & 6 & 0.3 \\
\hline \multirow[t]{2}{*}{ Marketing } & Cooperative & 3 & 32 & & 24 & 16 & \\
\hline & Non-cooperative & 6 & 29 & 1 & 13 & 17 & 1 \\
\hline
\end{tabular}

* represents high significance $(\mathrm{P}<0.05)$. 


\section{Perception of fish farmers towards cooperatives}

The cooperative fish farmers were given seven different reasons for choosing a cooperative and reasons were ranked I to VII, respectively (Table 5). Major reasons to join cooperative were saving schemes, followed by easy access to the cooperative branch office, lower interest rates and service fees, convenient services, marketing service and farm input availability in decreasing order. It was claimed that cooperatives do not make much contribution in fish marketing service and farm inputs in case of fish culture.

Table 5. Reasons to choose cooperative by farmers in Chitwan and Nawalpur districts

\begin{tabular}{lllll}
\hline & Chitwan & \multicolumn{3}{l}{ Nawalpur } \\
\cline { 2 - 5 } Reasons to choose cooperative & Index & Rank & Index & Rank \\
\hline Saving & 5.00 & I & 5.00 & I \\
Easy access to branch office of cooperative & 3.89 & III & 4.97 & II \\
Low interest rates & 4.94 & II & 3.33 & IV \\
Low service fees & 2.91 & V & 3.97 & III \\
Convenient services & 3.54 & IV & 2.77 & V \\
Marketing services & 1.83 & VI & 1.00 & VII \\
Access to farm inputs & 1.37 & VII & 1.80 & VI \\
\hline
\end{tabular}

Cooperative fish farmers were given 6 different points to assess their perceptions towards cooperatives (Table 6) and their level of satisfaction were measured as highly agree, agree, indifference, disagree and highly disagree
(Table 6). The value of satisfaction index was positive for access to socio-economic resources such as loan, subsidies, and services, and negative for its role in fish farming improvement in both districts.

Table 6. Satisfaction index for perception of fish farmers towards cooperatives in Chitwan and Nawalpur districts

\begin{tabular}{llc}
\hline Perceptions & \multicolumn{1}{c}{ Satisfaction Index } \\
\cline { 2 - 3 } & Chitwan & Nawalpur \\
\hline Access to loan and subsidies & 1.00 & 1.00 \\
Keeps good relation with farmers & 0.94 & 0.37 \\
Quality service to farmers & 0.51 & 0.10 \\
Solves fish farming problem & 0.37 & -0.73 \\
Improves aquaculture & -0.37 & -0.79 \\
Provides training in fish farming & 0.11 & -0.80 \\
\hline
\end{tabular}

\section{Discussion}

The Nepal government has been promoting cooperatives as beneficial for small--holder farmers (MoAD, 2016; NPC, 2019) and cooperatives have been mentioned as having a significant role in the economic empowerment of small-holder farmers globally (Hasan et al. 2020; Kemkhadze, 2017). In Nepal, most cooperative activities are more focused on saving and credit schemes rather than increasing agriculture production and productivity. It is essential to examine how these cooperatives are effectively working to better off fish farmers and improve fish farming production in Nepal.
The present study showed that majority of fish farmers belonged to the prime working age group of 30-50 years and were educated (Sharma et al. 2018) in both cooperative and non- cooperative categories in both districts. The family size of the households sampled were mostly with medium size family containing 5-7 members similar to Sharma et al. (2018) with average family members of households recorded 6 . There were a higher number of women fish farmers in Chitwan than Nawalpur due to the FFD funded women fish farmers empowerment projects implemented in eight village development committees, compared to Nawalpur where only 


\section{Our Nature | December 2020 | 18 (1): 1-9}

one village development committee wasinvolved in the same (Woynarovich, 2017).

The scale of fish farming and fish farmers were assessed based on land size, pond number and total pond area. Cooperative fish farmers had smaller farm size and pond area including pond number in both districts indicating that cooperatives are able to incorporate small scale fish farmers in their cooperative activities. Noncooperative fish farmers allocated larger area for pond (34\% in Chitwan and $84 \%$ in Nawalparasi) than cooperative fish farmers (33\% in Chitwan and $69 \%$ in Nawalparasi) resulting into higher fish production and income from fish sale. Noncooperative fish farmers seemed to have adopted fish farming commercially for income generation as they have large ponds for fish production and their total annual income from fish was also significantly higher $(\mathrm{P}<0.05)$.. The present study showed that majority of coopera-tive farmers are small-holder fish farmers in both districts. In small-holder farming, a large portion of production is consumed at home and shared with relatives.

Cooperative fish farmers were involved in five different types of cooperatives viz. agriculture cooperatives, fish farmer cooperatives, multi-purpose cooperatives, dairy cooperatives and forestry cooperatives in descending order. However, there was a total higher number of fish farmers in fish farmers cooperatives than in agriculture cooperatives in Chitwan because there are four fish farmers cooperatives in Chitwan compared to two in Nawalpur.

A majority of non-cooperative fish farmers were engaged in fish farmers self-help groups (94\% in Chitwan and $85 \%$ in Nawalpur). The self-help group concept has become very popular among farmers nowadays, and such self-help groups also have similar system of saving and credit. Self-help groups equally benefit memberfarmers with financial support through their own saving as well as help to link government and non-government organizations for subsidies and donations, and technical support in the training and extension process. In addition, the requirements for registering cooperatives are more stringent than for self-help groups, including the minimum number of farmers. In other studies, focusing on small-holder fish farming activities (Hasan et al., 2020; Hough and Bueno, 2002), cooperatives and self-help groups have been grouped together as FOs contrary to this study, where self-help groups have been separated from cooperatives. It would be interesting to explore the findings where cooperatives and self-help groups are joined into one category.

Non-cooperative farmers were facing significantly more challenges $(p<0.05)$ especially in seed quality and quantity, than cooperative farmers indicating that cooperatives are providing services satisfactorily in Chitwan. It should be noted that non -cooperative farmers in Chitwan did not also report other major problems, either.

In Chitwan, many fish farmer cooperatives are working addressing the farmer's problems, and supplying the farm inputs such as feed ingredients, fertilizers, chemicals for disease control at a reasonable price with establishment of cooperative shops. Some cooperatives are engaged in marketing for instance with the establishment of cooperative fish shops, which help the farmers to secure good sales prices. Self-help fish farmer groups in Chitwan also work in similar ways and at least the FFD funded projects have supported women fish farmer FOs regardless of their status being cooperative or self-help group.

In contrast to Chitwan, there were more feed problems among cooperative fish farmers in Nawalpur. A majority of the cooperative fish farmers in Nawalpur were engaged in agriculture cooperatives, which do not have fish farming in its mission. This indicated need of fish farmer cooperatives for helping fish farmers in farm inputs.

The negative value of satisfaction index regarding the cooperatives role in fish farming improvement and solving tfish farming problems reflected the position of fish farmer cooperatives. Fish farmers receive fish farming training and extension services only from fish farmer cooperatives and not from other types of cooperatives. In addition, the FFD supported FOs have received support in fish farming training and extension services, indicating that external support has been necessary to enable these services.

Small capital formed by small savings of farmers, low work efficiency in service provision and lack of sustainability in employment activities, and the limited functioning of saving and credit activities maybe the reasons that cooperatives are not popular among the fish farmers, in addition to the stringent requirements for minimum member level, etc. Though fish 


\section{Our Nature | December 2020 | 18 (1): 1-9}

farmer cooperatives are few in number they are making efforts to improve the status of their fish farmer members and to sustainably develop fish farming. Although the perception of the fish farmers (Table 6), depicts that fish farmers deem cooperatives as not having a positive effect on fish farming, the results in (Table 4) show that cooperative farmers fair much better in terms of less problems with seed, feed, fertilizer and disease. The negative perceptions of cooperatives may stem from other issues not actually related to those that were listed on the questionnaire, including for instance heavy workload for cooperative leadership. Fish farmer cooperatives are small and run by their members, with individual farmers taking time off from farming work to manage the cooperative. They may not also have the business skills to run the cooperatives (Kemkhadze, 2017). Moreover, farmers' perceptions in the present study was in general for all kinds of cooperative not just fish farmers cooperatives in particular.

Nepal's new constitution has given high priority to cooperatives particularly to agricultural cooperatives with aim to improve socio-economic condition of rural people. The role of fish farmer cooperatives is crucial in the fish farming in Nepal as it allows for the participation of small-holder fish farmers and marginalized groups like women, who may otherwise find it very difficult to carry out fish farming activities. Cooperatives thereby are a voice of small-holder fish farmers. Cooperatives have allowed for the sustainable development of the sector by providing inputs and cooperative fish farmers have less problems with fish farming activities than non-cooperative farmers. Collective bargaining on behalf of members and facilitation of training and extension services through access to government, academic institutions, linkages with international technical and donor agencies (Hasan et al., 2020) is also possible through cooperatives and this holds true in Nepal, too.

The proposition is that deeper efforts to support fish farmer cooperatives are made. It is inherent to gain a clear picture of fish farmer cooperatives nationally and thus a recommendation is to conduct a nation-wide status review of fish farmer cooperatives. This survey provides only but a window into the sector. The recommendation is also to categorise cooperatives and self-help groups as one category of fish farmer FOs, in order to gain a better understanding of their particular needs and to enable better comparison with similar reviews done in the Asia-Pacific region.

Studies in the Asia-Pacific region (Hasan et al., 2020; Hough and Bueno, 2002) demonstrate that fish farmer cooperatives and other FOs have great potential to develop fish farming sustainably and to empower their members socially and economically provided that there is a supportive and inclusive policy and enabling environment. Particular attention needs to be paid in terms of capacity building, in especially smallholder FOs, to ensure their viability and provision of services such as market access in order to improve their competitive advantage.

\section{Acknowledgments}

The authors would like to thank Mr. Sovan Mahato and Ms. Usha Chaudhary for their help in conducting the survey. We are also thankful to all farmers who participated in the survey. Data used in this research was collected as a part of the Empowering Smallholder Farmers in Markets (ESFIM) project supported by AgriCord.

\section{References}

Budhathoki, R. and B. Sapkota. 2018. Fish Farming in Nepal: Trend and Consumption Level. Acta Scientific Agriculture, 2(9): 109-115.

CFPCC. 2019. Central Fisheries Promotion and Conservation Centre. Annual report. Balaju, Kathmandu.

DEOC. 2020. Department of Co-operatives. New Baneshwor, Kathmandu. Retrieved from https://www.deoc.gov.np/. Accessed 6.12.2020

Hasan, M.R., Bueno, P.B. and Corner, R.A. 2020. Strengthening, empowering and sustaining small-scale aquaculture farmers' associations. FAO Fisheries and Aquaculture Technical Paper No. 655. Rome, FAO. 190 pp. https://doi.org/10. 4060/ c7741e. Accessed 19.12.2020

Hough, C. and Bueno, P. 2002. Producer associations and farmer societies: support to sustainable development and management of aquaculture. In FAO Review of the state of world aquaculture, pp. 75-86. FAO Fisheries Circular No. 886. Rome, FAO. 95 pp. 


\section{Our Nature | December 2020 | 18 (1): 1-9}

Kemkhadze, S. 2017. Cooperatives and Agriculture. The Kathmandu Post. Retrieved from https://www.ukessays.com/ essays/englishagriculture-cooperative-societies-englishlanguage-essay.php. Accessed 5.12.2020

MoAD. 2016. Agriculture Development Strategy (ADS) 2015 to 2035. Ministry of Agricul-ture Development. Singhadurbar, Kathmandu.

Ndifon, H.M., E.I. Agube and G.N. Odok. 2012. Sustainability of agricultural cooperative societies in Nigeria: The case of SouthSouth Zone, Nigeria. Mediterranean J. Soc. Sci. 3(2):19-25.

NPC. 2019. National Planning Commission. $15^{\text {th }}$ Plan Approach paper. Singhadurbar, Kathmandu.
Ortmann, G.F. and R. King. 2007. Agricultural cooperatives II: Can they facilitate access of small-scale farmers in South Africa to input and product markets? Agrekon, 46(2): 219244. doi: 10.1080/03031853.2007. 9523769 Accessed 5.12.2020

Sharma, T., Dhakal, S., Kattel, R., Gharti, K. and Lamichhane, J. (2018). Economics of fish production at Chitwan district, Nepal. Journal of Agriculture and Natural Resources, 1(1): 21-31. doi: 10.3126/janr. v1i1.22219. Accessed 5.12.2020.

Woynarovich, A. 2017. Evaluation of "Twinning Support for Empowering Women's Fish Farming in Nepal". Food and Forestry Development Finland. 